\title{
АНАЛІЗ ВПЛИВУ ШАРУ НАКИПУ НА КОЕФЦЦЕНТ ТЕПЛОПЕРЕДАЧІ У ГОРИЗОНТАЛЬНОМУ КОЖУХОТРУБНОМУ ТЕПЛООБМІННИКУ
}

У статті досліджено вплив товщини шару накипу у горизонтальному кожухотрубному теплообміннику на коефіиієнт теплопередачі від гарячої до холодної води. Розглядаються питання утворення шару накипу на поверхнях теплообмінного обладнання, види накипу та методи боротьби з накипом. За результатами розрахунків лінійних коефіцієнтів теплопередачі горизонтального кожухотрубного теплообмінника при протитечї гарячої води в трубках без шару накипу $i$ з урахуванням змінної товщини накипу з часом проведений аналіз ефективності теплопередачі по довжині апарату.

Ключові слова: кожухотрубний теплообмінник, накип, протитечія, трубна поверхня, теплопередача.

(c) Казак I. O., 2019.

Постановка проблеми. Багато фахівців відзначають, що несвоєчасна очистка теплообмінного обладнання і погана хімводопідготовка знижують теплову ефективність апаратів на 50-70\% [1]. Важливим фактором для ефективного застосування теплообмінного обладнання є необхідність передбачити якість теплоносія, його жорсткість.

У теплообмінниках хімічних виробництв та систем теплопостачання використовується сира водопровідна вода. Перед тим як воду нагріти і відправити до теплообмінного обладнання, іiі потрібно підготувати (пом'якшити, видалити гази, очистити від механічних домішок) [2]. Далі йде процес деаерації води, це процес видалення з води шкідливих газів, які служать однією з головних причин зародження корозії на обладнанні. Якщо у воді у великій кількості присутній кисень $\left(\mathrm{O}_{2}\right)$ і вуглекислий газ $\left(\mathrm{CO}_{2}\right)$, то при нагріванні швидкість корозії значно зростає. При неякісній водопідготовці для теплообмінного обладнання 3 часом будуть утворюватися шари накипу, відкладення, що ведуть у свою чергу до негативного впливу на процес теплопередачі у теплообмінниках і корозії на поверхнях обладнання.

Теплообмінник - дуже важливий елемент в системі опалення і гарячого водопостачання. При високому вмісті в воді накипеутворюючих солей режим роботи теплообмінників швидко порушується.

Кожухотрубні теплообмінники - це найпоширеніший на сьогоднішній день тип теплообмінників. Вони широко застосовуються в хімічній, нафтохімічній, харчовій, целюлозно-паперової промисловості, в енергетиці, суднобудуванні та машинобудуванні, компресорних станціях і холодильній техніці.

Аналіз попередніх досліджень. Стаття присвячена питанням утворення шару накипу на поверхнях теплообмінного обладнання, також розглядаються види накипу у теплообмінниках та окремі методи боротьби 3 накипом. Загальною науковою проблемою $є$ дослідження впливу шару накипу на коефіцієнт теплопередачі у кожухотрубних апаратах, невирішеною частиною наукової проблеми $є$ дослідження впливу зміни шару накипу у трубній поверхні нагріву з водою при протитечії на коефіцієнт теплопередачі горизонтального кожухотрубного теплообмінника.

Дану проблему досліджено у багатьох працях [2-9]. У роботі [5] розглянуто вплив накипних відкладень у кожухотрубних i пластинчастих теплообмінних апаратів 3 рідинними теплоносіями на коефіцієнт теплопередачі та температурний напір, крім цього виявлено, що накип надає згубний вплив на гідродинамічні показники апаратів. 3 ростом накипних відкладень в діапазоні 0,1 мм 1 мм, відбувається недовідпуск теплоти, для мінімізації його відбувається збільшення витрати теплоносія, що призводить до збільшення витрати палива і електроенергії на підігрів гарячого теплоносія теплообмінника. У статті [7, с.253] розглядаються питання мінімізації енергетичних затрат в кожухотрубних теплообмінниках з рідинними теплоносіями, 3 практики експлуатації доведена перевага кожухотрубних апаратів за ефективністю з протитечією, де можна нагріти холодний теплоносій до температури вищої ніж гаряча кінцева температура теплоносія, чого не можна досягнути для теплообмінників з прямотечією. У джерелі $[9$, с. 4] відмічається, що товщина шару накипу вже в 1 мм призводить до зниження коефіцієнта теплопередачі в 2 рази у кожухотрубному теплообмінному апараті і в 2,5 рази у пластинчастому теплообмінному апараті, що в свою чергу веде відпустці теплоносія більш низьких параметрів. У роботах $[2,11,12,13,14]$ запропоновані методики для розрахунку теплопередачі у теплообмінних апаратах з метою оцінки ефективності їх роботи.

Аналіз розглянутих джерел показав, що питання впливу товщини шару накипу з часом утворення на коефіцієнт теплопередачі у трубній поверхні нагріву саме для горизонтального кожухотрубного теплообмінника розглянуто недостатньо ніж для існуючих інших типів теплообмінних апаратів, що свідчить про його актуальність. 
Метою статті $є$ дослідити і проаналізувати як впливає товщина шару накипу трубної поверхні нагріву 3 часом утворення на коефіцієнт теплопередачі по довжині горизонтального кожухотрубного теплообмінника.

Виклад основного матеріалу. Кожухотрубні теплообмінники відносяться до найбільш поширених апаратів. Їх застосовують для теплообміну і термохімічних процесів між різними рідинами, парами $\mathrm{i}$ газами - як без зміни, так і зі зміною їх агрегатного стану [3].

Кожухотрубні теплообмінники з'явилися на початку ХХ століття в зв'язку з потребами теплових станцій в теплообмінниках з великою поверхнею, таких, як конденсатори і підігрівачі води, що працюють при відносно високому тиску [4]. У хімічній промисловості кожухотрубні теплообмінники застосовуються в якості конденсаторів, підігрівачів і випарників. В даний час їх конструкція в результаті спеціальних розробок з урахуванням досвіду експлуатації стала набагато більш досконалою. У ті ж роки почалося широке промислове застосування кожухотрубних теплообмінників в нафтовій промисловості. Теплообмінникам часто доводилося працювати із забрудненими рідинами при високих температурах i тисках, i тому їх необхідно було конструювати так, щоб забезпечити легкість ремонту та очищення.

3 роками кожухотрубні теплообмінники стали найбільш широко застосовуваним типом апаратів. Це обумовлено перш за все надійністю конструкції, великим набором варіантів виконання для різних умов експлуатації, зокрема: однофазні потоки, кипіння і конденсація по гарячій та холодній сторонам теплообмінника 3 вертикальним або горизонтальним виконанням; діапазон тиску від вакууму до високих значень; в широких межах змінюються перепади тиску по обидва боки внаслідок великої різноманітності варіантів; задоволення вимог по термічним напруженням без істотного підвищення вартості аппарату; розміри від малих до гранично великих $\left(5000 \mathrm{~m}^{2}\right)$; можливість застосування різних матеріалів відповідно до вимог до вартості, корозії, температурному режиму і тиску і т.п.

Кожухотрубні теплообмінники являють собою апарати, виконані з пучків труб, скріплених за допомогою трубних решіток і розміщених в кожусі з входом і виходом для заповнення його середовища. Традиційний кожухотрубний теплообмінник не допускає теплообміну між середовищами, що заповнюють ємність кожуха і внутрішній обсяг трубок, здійснюється через стінки трубок при зустрічному русі не змішенням середовищ. Трубки робляться з стійких до корозії металів, таких як латунь або нержавіюча сталь. Додання трубкам кожухотрубних теплообмінників потрібного профілю дозволяє підвищити їх площу теплопередачі в 2-3 рази. В результаті цього за деякими характеристиками кожухотрубні теплообмінники наближаються до пластинчастих приладів, але при цьому мають краще співвідношення між тепловіддачею і значенням гідравлічних втрат. Крім цього такі теплообмінні апарати дозволяють застосовувати будь-які види очищення, включаючи кавітаційно-ударні методи, які часто мало прийнятні для інших видів теплообмінників. Однак і для цього виду теплообмінників притаманне утворення відкладень. Для зниження ймовірності їх утворення можуть застосовуватися різні прийоми. У ряді випадків використовується так звана реверсивна схема, яка, по суті, є противотечійною подачею теплоносія і обігріваємої води. Такий вид руху теплоносія дозволяє зменшити обсяг застійних зон з 25-30\% до 5\%. Зменшення обсягу застійних зон скорочує і технічне утворення відкладень [6].

На рисунку 1 представлена традиційна схема горизонтального кожухотрубного теплообмінника при протитечії теплоносіїв в процесі теплопередачі. Труби і інші елементи конструкції кожухотрубного теплообмінника можуть бути виготовлені з вуглецевої або нержавіючої сталі. В кожусі 1 розміщений трубний пучок, теплообмінні труби 2 якого розвальцьовані в трубних решітках 3. Трубна решітка жорстко з'єднана 3 кожухом. 3 торців кожух апарата закритий розподільчими камерами 4 і 5. Кожух і камери з’єднанні фланцями. Для підводу і відводу теплоносіїв теплообмінник забезпечений штуцерами. Гаряча вода подається і рухається по трубкам, а холодна вода - в між трубному просторі, який обмежений кожухом і зовнішньою поверхнею труб. Особливістю в даній конструкції є те, що труби жорстко з'єднанні з трубчастими решітками, а решітки приварені до кожуха [11, с. 19].

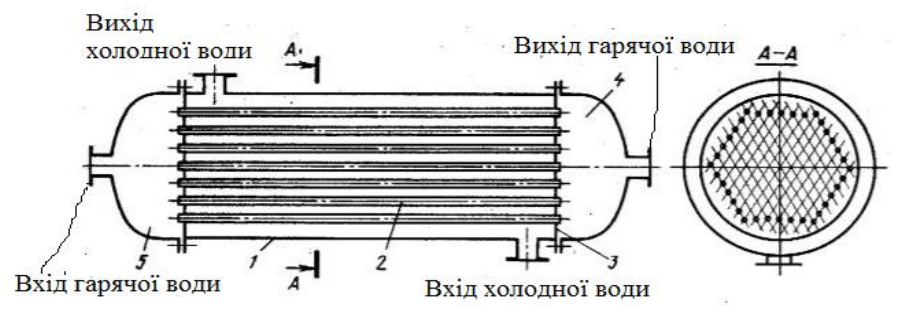

1 - кожух; 2 - теплообмінні труби; 3 - трубні ремітки; 4, 5 -розподільчі камери

\section{Рис.1 - Схема горизонтального кожухотрубного теплообмінника}

На хімічних виробництвах та системах теплопостачання на поверхнях нагріву теплообмінних апаратів утворюються відкладення, що відносяться до так званих низькотемпературних. Основними компонентами таких відкладень $є$ силікати, карбонати кальцію, а також оксиди заліза і сульфати кальцію.

Видів накипу багато і для кожного варіанту можна застосувати той чи інший спосіб видалення або запобігання їі утворення. Види накипу наведені в таблиці 1 [9, с. 3]. 
Визначаючись $з$ методами боротьби від накипу, необхідно попередньо зробити аналіз накипу і визначити його склад, щоб дізнатися, чим краще такий наліт розчиняти. Вода покриває $72 \%$ земної поверхні, це річки, моря, озера, підземні води і т.п., і звичайно вона має різний склад, десь вона занадто жорстка, а десь дуже м'яка. Потім визначається складність теплообмінного обладнання (залежить від його призначення), ступінь його забрудненості. Від усіх цих факторів залежить, чим і як потрібно видаляти накип.

Таблиця 1 - Характеристики видів накипу у теплообмінниках

\begin{tabular}{|l|c|c|}
\hline \multicolumn{1}{|c|}{ Вид накипу і його хімічний склад } & Характер відкладення & $\begin{array}{c}\text { Коефіціент } \\
\text { теплопровідності, } \\
\text { Вт/(м·К) }\end{array}$ \\
\hline $\begin{array}{l}\text { Силікатний накип (з вмістом } \mathrm{SiO}_{2} 20-25 \% \text { i } \\
\text { більше) }\end{array}$ & твёрдий & $0,06-0,23$ \\
\hline Гіпсовий накип (з вмістом $\mathrm{Ca}_{2} \mathrm{O}_{3}$ до 50\%) & твердий, щільний & $0,6-2,9$ \\
\hline $\begin{array}{l}\text { Карбонатний накип (3 вмістом СаСО3, } \mathrm{MgCO} 3 \\
\text { більше 50\%) }\end{array}$ & $\begin{array}{c}\text { від аморфного порошку до } \\
\text { твердого котельного каменю }\end{array}$ & $0,6-7,0$ \\
\hline $\begin{array}{l}\text { Змішаний накип, що складається з гіпсу, } \\
\text { карбонатів і силікатів кальцію та магнію }\end{array}$ & твердий щільний & $0,8-3,5$ \\
\hline
\end{tabular}

Крім очищення теплообмінного обладнання від вже утворенного накипу, є можливість запобігти його швидкого утворення на тому чи іншому обладнанні, для цього використовують всілякі фільтри або реагентні пом'якшувачі.

Приклад успішного застосування пом'якшувача води “Рапресол” для захисту від накипу кожухотрубного теплообмінника GSD Wärmetechnik (Німеччина), встановленого в м. Міллерово (Ростовська обл.) [8]. Для відновлення розрахункового режиму роботи потрібно висновок про теплообмінник з експлуатації та чистка забруднених поверхонь. В результаті використання пом'якшувача води “Рапресол” навіть при жорсткій воді (14 мг-екв/л), поверхня труб вільна від накоксованних відкладень накипу. Наявність шламу в міжтрубному просторі у вигляді тонких лусочок пояснюється мінімальною витратою води, що нагрівається в нічний час (до 1 м³/год). Пом'якшувач води “Рапресол” дозволяє: збільшити період між чистками теплообмінників, в результаті чого зменшуються експлуатаційні витрати на обслуговування; зменшити витрату теплоносія (циркуляцію мережної води) i, як наслідок, зменшити гідравлічні і теплові втрати; отримати економію електроенергії, споживаної насосами; знизити температуру мережної води в зворотному трубопроводі; підвищити ефективність використання теплоносія [8].

Ще одним засобом пом'якшення води є застосування системи водопідготовки “Гідрофлоу” для захисту від накипу теплообмінного, масообмінного обладнання, яка дає можливість: використовувати в якості підживлювальної непідготовлену (“сиру”) воду, “технічної якості”, з перевищенням в рази гранично допустимих концентрацій по жорсткості, залізу та ін.; збільшити ефективність теплообміну, масообміну до рівня нового обладнання; збільшити в кілька разів інтервали між зупинками теплообмінників для очищень; істотно скоротити час, який необхідний для очищення теплообмінника; подовжити термін служби обладнання - внутрішня корозія буде істотно уповільнена [10].

Основний принцип фізичної обробки води в тому числі ультразвуком і електромагнітними імпульсами полягає в тому, що при обробці проявляється ефект кавітації. Кавітація (від лат. Cavitas - порожнеча) - утворення в рідині порожнин (кавітаційних бульбашок, або каверн), заповнених паром. Кавітація виникає в результаті місцевого зниження тиску в рідині, яке може відбуватися або при збільшенні iii швидкості. В результаті кавітації у воді підвищується ймовірність зіткнення іонів кальцію і магнію, за рахунок чого утворюються зародкові центри кристалізації, які є енергетично більш вигідними порівняно зі звичайними місцями утворення накипу (стінками труб, нагрівальними поверхнями), отже накип починає утворюватися не де попало, а на створених центрах кристалізації - в обсязі води [9].

Тобто, спостерігаються два ефекту від ультразвукової обробки води: перешкоджання утворенню накипу i руйнування вже сформованого шару накипу. Так, при озвучуванні води ультразвуком достатньої інтенсивності відбувається руйнування, розколювання утворюються в нагрівається воді кристалів солей жорсткості. Це призводить до зменшення розмірів кристалів і до збільшення центрів кристалізації в нагрівається воді. В результаті значна частина кристалів не досягає розмірів, необхідних для осадження, $\mathrm{i}$ процес формування накипу на теплообмінних поверхні сповільнюється. Наступним механізмом впливу ультразвукової технології на освіту накипу служить збудження високочастотних коливань на поверхні теплообміну. Поширюючись по всій поверхні теплообмінного обладнання, ультразвукові коливання перешкоджають формуванню на ньому накипних відкладень, відштовхують від теплообмінної поверхні кристали солей і уповільнюють їх осадження.

Також застосовуються електромагнітні імпульси для боротьби з накипом у теплообмінниках, які впливають на воду в теплообміннику в такий спосіб. У необробленої воді при нагріванні зазвичай утворюються кристали карбонату кальцію (крейди, вапняку), форма яких схожа на реп'ях (промені 3 колючками, що розходяться в різні боки). Завдяки цій формі кристали з'єднуються між собою як гачки 3 застібками і, відповідно, утворюють складно видаляються вапняні відкладення - тобто накип, у вигляді дуже 
щільної, твердої кірки. Безреагентний пом'якшувач води Calmat за допомогою електромагнітних імпульсів впливає на воду природним шляхом і змінює процес кристалізації солей жорсткості. Блок управління виробляє динамічні електричні імпульси різних характеристик, які передаються через провід-обмотку на трубі в воду. Після обробки приладом вапно (кристали карбонату кальцію) утворюються в формі паличок. Отже, на відміну від обробки води ультразвуком, ми маємо три ефекти від електромагнітних імпульсів: перешкоджання утворенню накипу, руйнування вже сформованого шару накипу і утворення захисного протикорозійного шару [9]. В процесі обробки води за допомогою електромагнітних імпульсів виділяється невелика кількість вуглекислого газу, який в воді утворює вуглекислоту, що перешкоджає виникненню звичайної і виразкової корозії в металевих трубах.

Звичайно, крім описаних теорій ефективності фізичних методів обробки води існує безліч інших. Проте, практика показує, що боротьба з накипом ультразвуком і електромагнітними імпульсами - сучасні і надійні технології, що розвиваються з науковою базою.

Ефективність процесу теплопередачі нового кожухотрубного підігрівача зазвичай відповідає 94-98\%, а в умовах експлуатації, в залежності від межпромивочного інтервалу, хімічного складу і структури накипу, ефективність теплопередачі може знижуватися до 60\% і більше, що призводить до відповідного зниження ефективності систем гарячого водопостачання і підвищення енергетичних втрат [11].

Найбільшою мірою до забруднення схильні теплообмінники гарячого водопостачання, в яких накип утворюється на поверхнях нагріву з боку проходу водопровідної води. В результаті утворення накипу зниження коефіцієнта теплопередачі підігрівачів за один рік експлуатації становить 5-7\%, за два роки - до 30\%, за три роки - 50\% і більше. Крім того, утворення відкладень в трубках підігрівачів призводить до підвищення їх гідравлічного опору, який досягає 0,2 МПа [11]. Вартість заміни, наприклад, латунної трубної групи в кожухотрубному теплообміннику може скласти 80-90\% від вартості апарату. Накип призводить до зниження терміну експлуатації обладнання. Шар накипу перешкоджає нагріву води і одночасно утрудняє відведення тепла від поверхонь нагріву. В результаті поверхня нагріву перегрівається і виходить 3 ладу.

На рис. 2 наведено залежність товщини шару накипу від 0,0001м до 0,002 м від часу експлуатації від 1 до 7 років кожухотрубного горизонтального теплообмінника, яка має практично лінійну залежність і прямо пропорційно зростає від часу [11].

3 технологій водопідготовки та методів пом'якшення води найбільш ефективним, на даному етапі дослідження, є магнітна обробка води або з використанням електромагнітних апаратів, так як вони відрізняються безпекою, надійністю роботи при стабільних параметрах води, низькими експлуатаційними витратами і екологічністю. Але в свою чергу застосування електромагнітних апаратів

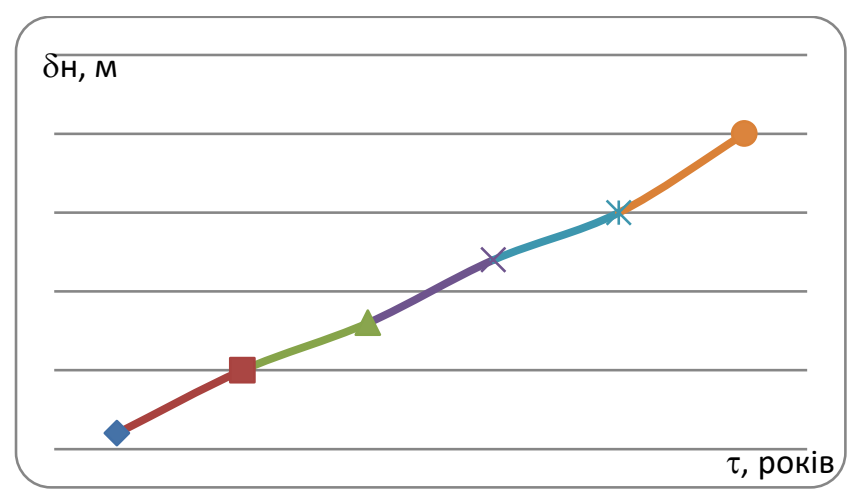

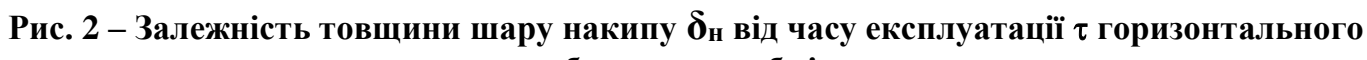
кожухотрубного теплообміннику

вимагає хімічної водоподготовки, а це введе до збільшення площі, займаної під теплообмінне обладнання, за рахунок додавання місця під блок хімічного водоочищення. Пом'якшення води для теплообмінного устаткування, яке застосовується в побуті або на приватних дрібних об'єктах може проводитися за рахунок фільтрів пом'якшення і безреагентного знезалізнення води [10, с. 4].

Проведені власні розрахунки за методикою [13, с.117] для горизонтального кожухотрубного теплообмінника для умов протитечії при зміні товщини карбонатного накипу $\delta$ в від 0,0005 м до 0,002 м 3 коефіцієнтом теплопровідності накипу $\lambda_{\mathrm{H}}=1,6 \mathrm{BT} /\left(\mathrm{M} \cdot{ }^{\circ} \mathrm{C}\right)$ на внутрішній поверхні трубок апарату зовнішнім діаметром 0,5 м $з$ тепловим навантаженням Q=690 кВт з гарячою водою з загальною жорсткістю 13,2 мг-екв/л, карбонатною жорсткістю - 6,1 мг-екв/л, температурою на вході у теплообмінник гарячої води $119 \cdot{ }^{\circ} \mathrm{C}$ та на виході $89 .{ }^{\circ} \mathrm{C}$ і холодної води на вході $-19 \cdot{ }^{\circ} \mathrm{C}$ та на виході $-36 \cdot{ }^{\circ} \mathrm{C}$. За результатами досліджень побудовано залежності коефіцієнту теплопередачі Klн від товщини накипу $\delta$ н (рис.3) та ефективності теплопередачі від товщини накипу $\delta$ н (рис.4). 


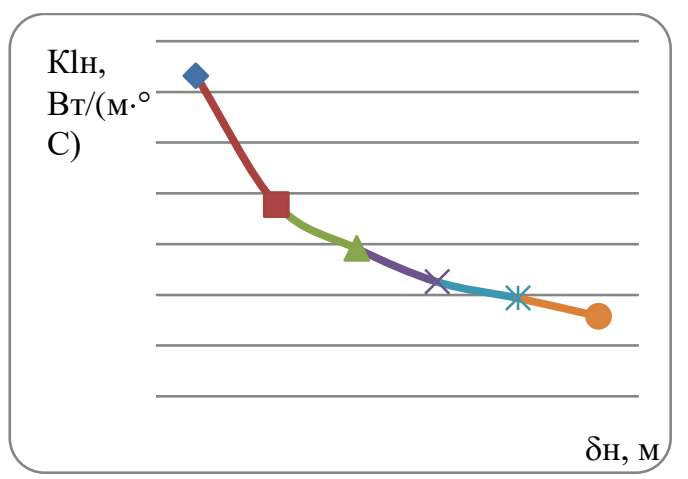

Рис. 3 - Залежність лінійного коефіцієнту теплопередачі $K_{\mathrm{ln}}$ від товщини шару накипу $\boldsymbol{\delta}_{\mathrm{H}}$ на внутрішній поверхні труб горизонтального кожухотрубного теплообмінника

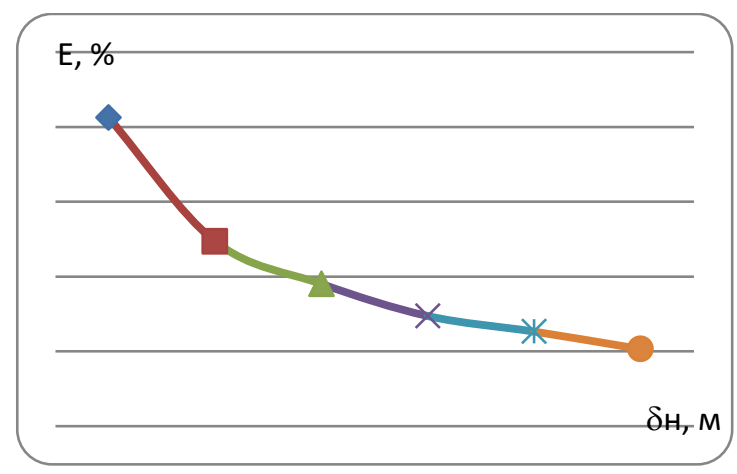

Рис. 4 - Залежність ефективності теплопередачі

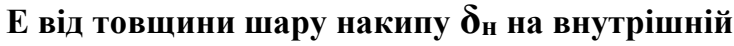
поверхні труб горизонтального кожухотрубного теплообмінника

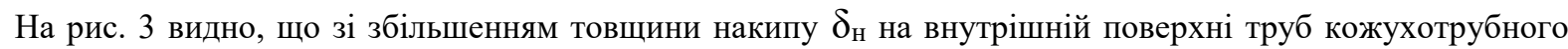
теплообміннику від 0,0001 м до 0,002 м лінійний коефіцієнт теплопередачі Кlн зменшується від 126,35 до $31,52 \mathrm{BT} /\left(\mathrm{м}^{\circ} \mathrm{C}\right)$, що свідчить про зниження ефективності процесу теплопередачі від гарячої води до холодної води у горизонтальному кожухотрубному теплообміннику від 77, 4\% до 20,59 \% в наслідок збільшення товщини накипу з часом відповідно від 1 до 7 років експлуатації апарату (Рис.4). 3 власних розрахунків для максимально обраної товщини накипу $\delta$ н на внутрішній поверхні труб з гарячою водою теплообмінного апарату 0,002 м лінійний коефіцієнт теплопередачі $\mathrm{Kl}$ н складає $31,52 \mathrm{BT} /\left(\mathrm{M} \cdot{ }^{\circ} \mathrm{C}\right)$ і в порівнянні 3 коефіцієнтом теплопередачі без накипу в 5 разів (на 80,1 \%) зменшується в наслідок утворення накипу $\left(\mathrm{Kl}=153,02 \mathrm{BT} /\left(\mathrm{M}^{\circ}{ }^{\circ} \mathrm{C}\right)\right.$ $\left.>\mathrm{K} l \mathrm{H}=31,52 \mathrm{BT} /\left(\mathrm{M}^{\circ} \mathrm{C}\right)\right)$. На рис. 3 і рис. 4 отримані залежності коефіцієнту теплопередачі і ефективності теплопередачі від зміни шару накипу у трубках з гарячою водою горизонтального теплообмінника в умовах протитечії мають вигляд гіпербол.

За результатами власних розрахунків і отриманих залежностей для горизонтального кожухотрубного теплообмінника при протитечії з урахуванням зміни шару накипу з часом на внутрішній поверхні трубок зробимо висновок, що товщина накипу 0,0005 м, яка утворюється через 3 роки експлуатації теплообмінника $\epsilon$ вже критичною з точки зору ефективності теплопередачі, тому що коефіцієнт теплопередачі знижується на 49 \% (Рис. 3) та відповідно ефективність теплопередачі знижується на 50 \% (Рис. 4) в порівнянні 3 поверхнею трубок без накипу $\left(\mathrm{Kl}=153,02 \mathrm{BT} /\left(\mathrm{M} \cdot{ }^{\circ} \mathrm{C}\right)>\mathrm{KlH}=75,57 \mathrm{BT} /\left(\mathrm{M} \cdot{ }^{\circ} \mathrm{C}\right)\right)$.

Висновки. У статті розглянуті види накипу і сучасні методи боротьби з ним для теплообмінних апаратів, такі як: самоочищення, застосування реагентних пом'якшувачів, ультразвук, магнітна обробка води. Виявлено 3 аналізу дослідження, що на даний час найбільш ефективним методом боротьби з накипом саме у кожухотрубних апаратах є магнітна обробка води за безпекою, надійністю роботи і т.п. Також виявлено в результаті розрахунків лінійних коефіцієнтів теплопередачі без накипу і зі змінним шаром накипу на внутрішній поверхні трубок з гарячою водою у горизонтальному кожухотрубному теплообміннику при протитечії суттєвий вплив товщини шару накипу на ефективність теплопередачі вже при товщині шару накипу поверхні нагріву 0,0005 м, вище якого неможливо ефективно забезпечити процес теплопередачі в апараті. Отриманні гіперболічні залежності коефіцієнту теплопередачі і ефективності теплопередачі від товщини шару накипу для горизонтальних кожухотрубних апаратів.

Перспективи подалыших досліджень. За даним дослідженням планується проаналізувати інші методи боротьби з накипом у теплообмінному обладнанні для підвищення ефективності теплопередачі між теплоносіями.

\section{Список використаної літератури}

1. Андрюшенко А.И. Теплофикационные установки и их использование / А.И. Андрюшенко, Р.3. Аминов, Ю.М. Хлебалин. - М.: Высш. школа, 1989. - 256 с.

2. Исаченко В.П. Теплопередача / В.П. Исаченко, В.А. Осипова, А.С. Сукомел. - М.: Энергоиздат, 1981. $415 \mathrm{c}$.

3. Кожухотрубный (кожухотрубчатый) теплообменник. Устройство и принцип работы [Електронний pecypc]. - Режим доступу: http://www.teploobmenka.ru/oborud/art-shelltube/

4. Типы кожухотрубных теплообменников, их основные узлы [Електронний ресурс]. - Режим доступа: http://chhmt.org.ru/uchebnik/TOO/430.php

5. Защита от накипи теплообменного и массообменного оборудования [Електронний ресурс]. - Режим доступу: http://www.plasma.com.ua/energy_saving_technologies/hydroflow/product3.html

6. Самоочистка теплообменников [Електронний ресурс]. - Режим доступу: https://aquatherm.ru/articles/articles_288.html

7. Грииай B.I. Мінімізація енергетичних затрат у кожухотрубних теплообмінниках з парорідинними теплоносіями [Електронний ресурс] / В. І. Грицай, Я. П. Юсик // Вісник Національного університету 
«Львівська політехніка»: Хімія, технологія речовин та їх застосування. - 2003. - № 488. - С. $252-$ 262. - Режим доступу: http://ena.lp.edu.ua:8080/handle/ntb/9745

8. Умягчитель воды "Рапресол" для защиты от накипи кожухотрубных теплообменников [Електронний pecypc]. - Режим доступу: http://annufa.ru/communhoz.html

9. Дебаркадер Л.А. Борьба с накипью ультразвуком и электромагнитными импульсами. [Електронний ресурс] / Л.А. Дебаркадер // Интересности и Полезности на Интереско.инфо. - Режим доступу: http://interesko.info/borba-s-nakipyu-ultrazvukom-i-elektromagnitnymi-impulsami/

10. Галковский B.A. Анализ снижения коэффициента теплопередачи теплообменных аппаратов вследствие загрязнения поверхности [Електронний ресурс] / В.А. Галковский, М.В. Чупова // Интернет-журнал “Науковедение” Том 9, №2 (2017). - Режим доступу: https://naukovedenie.ru/vol9-2-technics.php

11. Волк Г.М. Исследование эффективности ультразвукового метода снижения скорости образования накипи в паяных пластинчатых теплообменниках [Електронний ресурс] / Г.М. Волк, В.З Галутин, В.П. Мелихова, В.П. Фролов, С.Н. Щербаков // АВОК. - Режим доступу: https://www.abok.ru/for_spec/articles.php?nid=2002

12. Виноградов С.Н. Выбор и расчет теплообменников: учебн. пособ. / С.Н. Виноградов, К.В. Таранцев. - Пенза.: Пензхиммаш, 2001. - 100 с.

13. Коваленко I.B. Розрахунки основних процесів, машин та апаратів хімічних виробництв. Навчальний посібник / І.В. Коваленко, В.В. Малиновський. - К: Норіта-плюс, 2006. - 212 с.

14. Касаткин А.Г. Основные процессы и аппараты химической технологии / А.Г. Касаткин. - М.: Химия, 1973. $-752 \mathrm{c}$.

Надійшла до редакції 26.12.2018

Kazak I.A.

\section{ANALYSIS OF THE INFLUENCE OF THE LAYER OF SCALE ON HEAT TRANSFER COEFFICIENT IN THE HORIZONTAL SHELL-AND-TUBE HEAT EXCHANGER}

Over the years, shell and tube heat exchangers have become the most widely used type of apparatus. This is primarily due to the reliability of the design, a large set of options for different operating conditions, in particular: single-phase flows, boiling and condensation on the hot and cold sides of the heat exchanger with vertical or horizontal execution; pressure range from vacuum to high values; sizes from small to very large $(5000 \mathrm{~m} 2)$ the possibility of using different materials in accordance with cost requirements, corrosion, temperature regime and pressure, etc. With poor water treatment for heat exchange equipment, over time, layers of scale, sediment will form, leading in turn to a negative impact on the heat transfer process in heat exchangers and corrosion on the surfaces of the equipment. The article investigated the effect of scale thickness in a horizontal shell-and-tube heat exchanger on the heat transfer coefficient from hot to cold water. The issues of creating a layer of scale on the surfaces of heat exchange equipment, types of scale and modern methods of dealing with it for heat exchangers, such as: self-cleaning, the use of chemical softeners, ultrasound, magnetic water treatment are considered. Identified by analysis of the study, currently the most effective method of dealing with scale in precisely shell-tube apparatus is magnetic water treatment due to safety, reliability of operation with stable water parameters, low operating costs and environmental friendliness. The article describes the traditional scheme of horizontal shell-and-tube equipment and features of its design. According to the results of calculations of linear heat transfer coefficients of a horizontal shell-and-tube heat exchanger with a counterflow of hot water in tubes without a layer of scale and taking into account the variable thickness of scale with the creation time, an analysis of the efficiency of heat transfer along the length of the apparatus was carried out. The obtained hyperbolic dependences of the heat transfer coefficient and heat transfer efficiency on the scale thickness for horizontal shell-and-tube heat exchangers. It was calculated and obtained that with an increase in the thickness of scale on the inner surface of pipes of a shell-and-tube heat exchanger from $0.0001 \mathrm{~m}$ to $0.002 \mathrm{~m}$, the linear heat transfer coefficient Kln decreases from $126.35 \mathrm{~W} /\left(\mathrm{m} \cdot{ }^{\circ} \mathrm{C}\right)$ to $31.5 \mathrm{~W} /\left(\mathrm{m} \cdot{ }^{\circ} \mathrm{C}\right)$, which indicates reducing the efficiency of the heat transfer process from hot water to cold water in a horizontal shell-and-tube heat exchanger from $77.4 \%$ to $20.59 \%$ as a result of an increase in the thickness of scale with a time of 1 to 7 years of operation of the apparatus, respectively. It was revealed as a result of calculating linear heat transfer coefficients of scale and with a variable layer of scale on the inner surface of hot water tubes in a horizontal shell-and-tube heat exchanger with countercurrent a significant effect of the thickness of the layer of scale on the heat transfer efficiency even at a thickness of the scale of the heating surface $0.0005 \mathrm{~m}$ above which it is impossible to efficiently to ensure the heat transfer process in the apparatus, since the heat transfer coefficient decreases by $49 \%$ and, accordingly, the heat transfer efficiency decreases by $50 \%$ compared to the surface of the tubes without scale $\left(153,02 \mathrm{~W} /\left(\mathrm{m} \cdot{ }^{\circ} \mathrm{C}\right)>\mathrm{KlH}=75,57 \mathrm{~W} /\left(\mathrm{m} \cdot{ }^{\circ} \mathrm{C}\right)\right)$.

Keyword:. shell-and-tube heat exchanger, scale, protection, pipe surface, heat transfer.

\section{References}

1. Andryushenko A.I., Aminiv, R.Z., Xlebalin, Yu.M. (1989). Teplofikacijni ustanovky`i yix vy`kory`stannya [Heating installations and their use], Vy`shha. Shkola, Moskov, USSR.

2. Isachenko V.P., Osy`pova, V.A., Sukomel, A.S. (1981). Teploperedacha [Heat transfer], Energoizdat, Moskov, USSR. 
3. Kozhuxotrubny`j (kozhuxotrubchasty`j) teploobminny`k. Pry`strij i pry`ncy`p roboty` [Shell-and-tube (shell-andtube) heat exchanger. Device and principle of operation], available at: http://www.teploobmenka.ru/oborud/artshelltube/

4. Ty`py`kozhuxotrubny`x teploobminny`kiv, yix osnovni vuzly` [Types of shell-and-tube heat exchangers, their main components], available at http://chhmt.org.ru/uchebnik/TOO/430.php

5. Zaxy`st vid naky`pu teploobminnogo i massoobmennogo obladnannya [Protection against scale of heat exchanging and mass transfer equipment], available at: http://www.plasma.com.ua/energy_saving_technologies/hydroflow/product3.html

6. Samoochy`shhennya teploobminny`kiv [Self-cleaning heat exchangers], available at: https://aquatherm.ru/articles/articles_288.html

7. Gry`czaj, V.I., Yusy`k, Ya. P. (2003). "The ministry of energy costs for shell-and-tube heat-exchangers with steam-cooled heat exchangers", Visny`k Nacional`nogo universy`tetu "L`vivs`ka politexnika": Ximiya, texnologiya rechovy`n ta yix zastosuvannya [Newsletter of the National University "Lviv Politekhnika": Chemistry, technology of speech and ix zastosuvannya], Lviv, Ukrain, available at: http://ena.lp.edu.ua:8080/handle/ntb/9745

8. Pom'yakshuvach vody“"Rapresol” dlya zaxy`stu vid naky`pu kozhuxotrubny`x teploobminny`kiv [Water softener "'Rapresol" for protection against scale of shell-and-tube heat exchangers], available at: http://annufa.ru/communhoz.html

9. Debarkader L.A. “Ultrasound and Electromagnetic Pulses”, Cikavy`nky`i Kory`sne na Interesko.info [Interesting and usefulness on Inteksko.info], available at: http://interesko.info/borba-s-nakipyu-ultrazvukom-ielektromagnitnymi-impulsami/

10. Galkovsky j, V.A., Chupov, M.V. (2017). "Analysis of the reduction in heat transfer coefficient of heat exchangers due to surface contamination", The online journal "Science Research, vol. 9, no 2, available at: https://naukovedenie.ru/vol9-2-technics.php

11. Vovk, G.M., Galutina, V.Z., Melixova, V.P., Frolov, V.P.,. Shherbakov S.N. (2002). “"The study of the effectiveness of the ultrasonic method of reducing the rate of scaling in brazed plate heat exchangers", $A V O K$, available at: https://www.abok.ru/for_spec/articles.php?nid=2002

12. Vy`nogradov, S.M., Tarancev, K.V. (2001). Vy`bir i rozraxunok teploobminny`kiv [Selection and calculation of heat exchangers], Penzximmash, Penza, USSR.

13. Kovalenko I.V., Maly`novs`ky`j, V.V. (2006). Rozraxunky`osnovny`x procesiv, mashy`n ta aparativ ximichnix vy`robny`cztv [Calculations of the main processes, machines and equipment for chemical production], Noritaplyus, Kyiv, Ukrain.

14. Kasatkin, A.G. (1973). Osnovni procesy` ta aparaty`ximichnoyi texnologiyi [Basic processes and apparatuses of chemical technology], Ximiya, Moskov, USSR. 